\title{
Actualization of Pancasila in The Implementation of Ethical Democracy in The Global Era
}

\author{
Nufikha Ulfah \\ MKU PPKn, Visual Communication Design Study Program, Institut Teknologi Sumatra (ITERA) \\ e-mail: nufikha.ulfah@staff.itera.ac.id \\ Arofah Minasari \\ International Relations, Faculty of Social and Political Sciences, Universitas Sebelas Maret \\ e-mail: arofah.minasari@staff.uns.ac.id \\ Yayuk Hidayah \\ Elementary School Teacher Education, Faculty of Teacher Training and Education, Universitas Ahmad \\ Dahlan \\ e-mail: yayuk.hidayah@pgsd.uad.ac.id
}

\begin{abstract}
As a value system, Pancasila provides a fundamental basis in the life of the community, nation, and state. The essence of the fourth principle of Pancasila is about democracy which is based on wisdom that is rooted in the moral principle of humanity and divinity. Therefore, according to the Pancasila view, democracy must be based on religious moral originating from God, justice and civilization. Nowadays, by seeing the application of democracy in Indonesia still has many problems, likes freedom as a symbol of democracy is not balanced with its quality, resulting in behavior that is contrary to democracy. Although freedom is guaranteed in the Constitution, oppression, discrimination, marginalization still occurs. Democracy does not only require laws, regulations, and institutions capable of enforcing it, but also democratic attitudes, namely the willingness to build a compromise with the awareness that a person cannot realize all that is desired (a combination of individual awareness and group awareness). True democracy requires good citizens. Therefore, democratic education that integrated through Citizenship Education is absolutely necessary with the aim of preparing citizens who are able to act with democratic ethics.
\end{abstract}

Keywords: Democratic Ethics, Pancasila Democracy, Civic Education

\section{INTRODUCTION}

Humans and human rights are two words that are difficult to separate. Since its birth on earth, human beings were born with the inherent natural rights inherent in their lives. Basically humans are free beings. Independence in expressing opinions is part of human rights. Freedom is a human demand as an individual being. On the other hand humans are social beings. Humans cannot live alone. They always live in the midst of their sociality, whether it's a small group of people, ethnic groups, nations or countries. In this position of human beings as social beings, human rights problems become complex. There are many human collisions with one another, one group with another group. Rights and freedoms naturally belong to every human being. In a group life, this right is taken or delegated to the group for joint living arrangements.

Every country must protect the human rights of citizen. In Indonesia, human rights are regulated in the 1945 Constitution Article 27-34 (UUD 1945 Pasal 27-34), including the right to freedom of association, assembly and in issuing opinions (Article 28E Paragraph 3). In Article 1 paragraph is explained that: "Kemerdekaan menyampaikan pendapat adalah hak setiap warga negara untuk menyampaikan pikiran 
dengan lisan. tulisan. dan sebagainya secara bebas dan bertanggung jawab sesuai dengan ketentuan peraturan perundang-undangan yang berlaku" (Law No. 09 of 1998 concerning Independence Delivering Public Opinion, n.d). It also explained about the principles and objectives in expressing opinions in article 3 paragraph (1), (2), (3), and (4) and article $4 \mathrm{a}, \mathrm{b}, \mathrm{c}$, and d, namely freedom of expression in public carried out based on principle of balance between rights and obligations; deliberation and consensus; legal certainty and justice; professional and benefits; and aims to realize responsible freedom as one of the implementation of human rights in accordance with Pancasila and the 1945 Constitution; legal protection in guaranteeing freedom of expression; realize the development of a conducive climate for the development of citizen participation and creativity as the realization of rights and responsibilities in democratic life; and able to place social responsibility in the life of the community, nation, and state, without neglecting the interests of individuals or groups. (Law N. 09 of 1998 concerning Freedom of Delivering Public Opinion, n.d.) (Undang-Undang No. 09 Tahun 1998 Tentang Kemerdekaan Menyampaikan Pendapat Di Muka Umum, n.d ).

Freedom of opinion is an implementation as human rights values. James W. Nickel wrote in his book entitled Making Sense of Human Rights, states that "when human rights are implemented in international law, we still call it human rights; but when it is implemented in domestic law, we tend to describe it as civil rights or constitutional rights,". As discussed earlier, in the context of Indonesian national law the constitutional rights of citizens regarding the right to freedom are given complete opinions in the Indonesian Constitution, namely the 1945 Constitution Article 28, Article 28E Paragraph (2) and Paragraph (3) (Udayana, 2013). Based on the explanation of freedom of expression, it is in line with Article 19 of the Universal Human Rights Declaration which reads: "Setiap orang berhak atas kebebasan mempunyai dan mengeluarkan pendapat, dalam hak ini termasuk kebebasan mempunyai pendapat dengan tidak mendapat gangguan dan untuk mencari, menerima, dan menyampaikan keterangan dan pendapat dengan cara apapun juga dan dengan memandang batasbatas." (PBB, n.d).

Freedom of opinion is the main foundation of modern democracy. The implementation of contemporary democracy is full of demonstrations. Demonstrations are a manifestation of freedom in expressing opinions. However, often for the sake of freedom to argue it collides with existing rules or norms which result in ethical violations. In fact, there are so many phenomena that show that freedom of expression is not based on responsibility. The freedom to express opinions now has a negative impact due to abuse of "rights" which can ultimately endanger others. Thus, violence and anarchist actions among the people are victims. Referring to this, the implementation of democracy in Indonesia cannot yet be accompanied by the enforcement of human rights. Based on the report on the Political Terror Scale (PTS), Indonesia is ranked third in human rights violations and also Indonesia has a poor record of human rights violations relating to political murder and brutality. Data from the 2008 Human Rights Feature Index confirmed PTS records. According to the 2007 Physical Integrity Rights Index, the index found in the Project Characteristics measures state records using four indicators, namely torture, extrajudicial killings, prison sentences and political disappearance. The Physical Index uses scores ranging from 0 to 8 where 0 does not indicate the government's appreciation of the four rights and 8 for the full respect of the government (Zezen Zainal Mutaqin, 2016: 173). 
Indonesia makes democracy a political system, so people get freedom in the political sphere such as opinions, organizations, and direct election of their leaders. As a democracy, freedom needs to be accompanied by upholding human rights so that freedom is not arbitrary. The implementation of democracy Indonesia is not a liberal democracy that upholds the absolute freedom of individuals and results in secularism and capitalism, and also not the proletarian democracy adopted by the communist socialist state. Indonesian democracy is a democracy based on Pancasila values. Therefore, Pancasila as the basis or ideology of the state must be applied in democratic life (Apiek Gandamana, 2017: 2). Alfian's lined, Pancasila as ideology of Indonesia as a through and indepth system of values; has a comprehensive coverage, which can be an umbrella for different interest and social dynamics because that regarding truth and justice in the life community (Alfian's opinion, 1981 in Siswanto, 2017: 146).

However, other facts show that Indonesia's achievement in holding political rights, freedom of citizens and the level of governance have increased since 2005, so that can be said to be relatively good. The level of public support for democracy in Indonesia is better than other regions in the world, such as in Asia and Africa viewed through various surveys of a number of respondents. The survey showed a rejection of the existence of military powers, the rules of one party, authoritarian ruler in decision making and the desire to get rid of parliament (Hendro Muhaimin, 34). It can be concluded that the meaning of democracy (government is from, by, and for the people) in Indonesia can be said to be relatively good, because the involvement of citizens in government activities has been carried out.

According to Huntington (1991), the world today, including Indonesia, is at the third wave of democratization which raises prominent issues of democratization, among others: reciprocal relations of economic development with the process of democratization and forms of democratic government, especially those related to individual freedom, political stability and their implications for international relations. To answer the problem of the underlying factors of the growth and development of the democratization process, although not in the context of a causal relationship, Huntington (1991) concludes that is "A High Correlation Between Western Christianity And Democracy ". With a statistical argument, that of the 68 countries considered democratic by $57 \%$ are predominantly Western Christians, and only $12 \%$ of the 58 dominant countries of other religions are democratic countries (Winataputra \& Budimansyah, 2012, p. 218). John L Esposito and John O. Voll (2016) conducted comparative studies of democracy in Iran, Sudan, Paskistan, Algeria, and Egypt. In his book "Islam and Democracy", Esposito and Voll (1996: 11): "Kebangkitan Islam dan demokratisasi di dunia muslim berlangsung dalam konteks global yang dinamis" (the rise of Islam and democratization in the Muslim world takes place in a dynamic global context) where is a process of strengthening communal identity and the demands for people's political participation that emerge in a complex world environment when technology is increasingly strengthening global relations, while at the same time local, national and local cultural identities are still very strong. Based on this, it can be indicated that the process of democracy should not always be measured by the criteria of western democracy, but seen contextually. Because democracy itself does not develop in a situation that is socio-culturally vacuum (Winataputra \& Budimansyah, 2012, p. 219). Ideal democracy that applied in Indonesia refers to prevailing values and norms in Indonesia and upholds the values and principles of democracy. Pancasila democracy which is an ideal also faces challenges to be implemented. Historically, in a 
number of periods it has been shown that the implementation of Pancasila Democracy cannot be done purely. These can be seen from a democratic system; (1) 1945-1949, political interaction and freedom of the press are limited. However, at this time the basic things of democracy have been laid, namely the granting of overall political rights, the president's constitutional rights tend to be dictatorial, and the establishment of political parties which are the foundation of the Indonesian party system regulated by the Vice President Decree; (2) 1949-1950, adopting a system of parliamentary government with a liberal democratic system; (3) 1950-1959, the enactment of the UUDS liberal democratic system; (4) 1959-1965, the enactment of guided democracy which emphasizes power in the president's hand. The definition of guided democracy on the fourth principle of Pancasila is led by representatives of wisdom in deliberations, but the president will interpret as "guided"; (5) 1966-1998, the enactment of the Pancasila Democracy system, however, in its implementation there were many deviations from Pancasila, namely the misuse of power and culture of corruption; and (6) 1998- present developed democracy, namely democracy based on Pancasila and the 1945 Constitution, the division of power (duty, authority), executive, legislative and judicial institutions are increasingly clear (Hendro Muhaimin, 28,29). In the post-reform era, Pancasila democracy experienced malpractice in Pancasila democracy. These situations weaken the good intentions to implement pure Pancasila democracy, such as; on-going political oligarchy, money politics, procedural-transactional politics, political dynasties, political rewards, and political short-sightedness (Muhyar Fanani, 2017: 218).

Externally, developments in the global, regional and national levels can affect "Proxy War" in Indonesia. Proxy War consists of three categories: politics / security; economy; and culture. Furthermore, the author will only discuss the third point, namely culture, where the target culture of proxy war is ideology, lifestyle, and mind-set (Siswanto, 2017: 144). Pancasila which is supposed to be a force to overcome the threat of war Proxies have been neglected from public life, so people have lost their guidelines to face the onslaught of globalization that has the potential to become a proxy war (Siswanto, 2017: 145). Therefore, it can be concluded that problems affecting Indonesian society are caused by ideological crises. Other history shows that there were several countries which were destroyed by ideological crises, such as the Soviet Union and Yugoslavia. These two countries were destroyed when their citizens began to abandon their country's ideology (Siswanto, 2017: 146,147). Therefore the Indonesian government and the community need to pay serious attention to the phenomena that occur in the global, regional, and national environment that might influence Indonesia.

Various discourses on the model of democracy that are compatible with the conditions of the Indonesian people who have "Bhinneka Tunggal Ika" (Unity in Diversity) with the intricacies of historical experience, economic development, and their interactions with the tendency of globalization are increasingly being developed. The development of the discourse shows that commitment to improve the quality of democratic life in Indonesia is experiencing a peak stage. In other words, the future of instrumentation and praxis of democratic life in Indonesia will experience continuous improvement in line with the dynamics of participation of all citizens in accordance with their position and role in society (Winataputra \& Budimansyah, 2012, p. 222-223). Because this democratization process involves this concerning citizen participation in the political process, then the preparation of citizens able to participate intelligently and responsibly which is an important issue in the current democratization process. As believed, that the ethos of democracy is not inherited, but studied and experienced. 
Therefore citizenship education as a vehicle for democratic education in a broad sense plays a strategic role, because it directly touches the potential target of democratic citizenship for various ages. Today, the democratization process that must be developed is not only for democracy, but also for the future democracy (Winataputra \& Budimansyah, 2012, p. 218).

Based on the explanation of the ethics concepts and democracy, it can be concluded that in realizing the application of ideal democracy needs to be a normative moral values and norms to regulate behavior in democracy participating. In this case, Indonesia has ideal values and norms that govern all the behavior of its citizens, namely Pancasila, which in its principles contains ideal ideals of the state for the continuation of the life of society, nation and state. Furthermore, the values and norms (Pancasila Democracy) will be further explained below.

\section{RESULT AND DISCUSSION}

\section{Democracy Ethics - Democracy Based On Pancasila}

Before discussing democratic ethics, the author will discuss about the concepts of ethics and democracy. The Greek philosopher Aristotle used the term ethics to indicate moral philosophy. Then "ethics" means the science of behavior of life or the knowledge of customs (in the plural). Ethics can also be explained as "science which discusses moral principles". The word "ethics" is commonly used in a sense of moral values and norms are used as guidelines for a person or group in regulating their behavior. Ethics deals with value problems because the subject matter of ethics is "good" and "bad". Ethics are normative to regulate human behavior which means giving norms to what must be done and not to do (Bertens, 1993, pp. 4-6). Daily activity needs to be a value and norm that regulates all behavior for a person or group. Democracy can be interpreted as people's power or authority. The term democracy is briefly defined as government or power from the people, by the people, and for the people. If viewed from the organization perspective, a democratic state is a country that is organized based on the will and will of the people, a democratic country, namely the state of people's sovereignty. Therefore Abraham Lincoln stated that democracy is "the government from the people, by the people, and for the people" (Student Affairs, 2016, p. 147). Democracy is not only a form of government, but also about how democracy is able to create a "peace" agreement between communities that departs from "shared" interests.

Based on this explanation, it can be concluded that in realizing the application of ideal democracy there needs to be a normative moral values and norms to regulate behavior in participating in democracy. In this case, Indonesia's the ideal values and norms that govern all the behavior of its citizens, namely Pancasila which in their principles contain ideal ideals of the state for the continuation of the life of society, nation and state.

Indonesia State is a united states whose democratic system is based on the principle of 'Kerakyatan yang dipimpin oleh hikmat kebijaksanaan dalam permusyawaratan/perwakilan'. The democratic country means multicultural, multiethnic nation and plurality in religious life will survive firmly when priority is not fulfilled the individual rights or only collective rights, but also the obligation to develop social solidarity (mutual cooperation) in order of the benefit and happiness of life of the nation. The principle of a populist democracy is the equality of citizens' srights by respecting minority rights (majority rule, majority rights) presupposes the existence of popular sovereignty based on a spirit of family. Therefore the main essence of principle 
"Kerakyatan yang dipimpin oleh hikmat kebijaksanaan dalam permusyawaratan perwakilan" (popularism is led by wisdom in representation) is not an individualistic democracy (Kaelan, 2013, p. 359-360). Based on this opinion, the Indonesian state is a democratic country that is based on the principle of "Kerakyatan yang dipimpin oleh hikmat kebijaksanaan dalam permusyawaratan perwakilan" (fourth principle) by upholding human rights as a principle of democracy and the obligation to develop mutual cooperation for the benefit of the people themselves.

Pancasila as the basis of Indonesian state philosophy is essentially a single unit of multiple compound constituents. The main point of the fourth principle, namely 'populist' that is human nature with the nature of the structure and implementation of the state cannot be separated as human nature is contained in the second principle of Pancasila and the third principle 'Persatuan Indonesia' (Indonesian Unity) which precedes, animates, and underlies the fourth principle (Kaelan, 2013, p. 360). Consultative democracy according to Soekarno has a dual function. On the other hand, the spirit of deliberation would strengthen the unity state. Unity is not for one group or individual, but for the achievement of a common good. The idea of "consultative democracy" based on the principles of Pancasila is the conscious effort of the nation's founder to do what is called Putnam, namely "making democracy work" or what Saward called "rooted" (to take root), in the Indonesian context. (Yudi Latif, 2012: 475).

As Hatta stated that the model of developing democracy was not only democracy which merely traced western culture, but also democracy that was in accordance with the character of Indonesian, namely family democracy based on deliberation. Latif (2011) added that Pancasila as part of social and political values that were prevalent in the twentieth century. Pancasila as part of social and political values should be placed in its position. Because the values contained in Pancasila are flexible in nature to be used as a handle even though they are currently in the global era. The existence of Pancasila must be actualized and given new interpretations and adapted to national and global dynamics. The implementation of Pancasila democracy with the idea of "deliberative democracy" has actually become the root. So, Pancasila democracy is not just an ideal and hope. But it can come true and grow as it should.

True democracy requires good citizens. Democracy not only requires laws, regulations and institutions that are able to enforce it, but also democratic attitudes that are supported by ethics in democracy especially in expressing opinions. In addition, in a democracy need to work together in building a compromise with the awareness that one cannot realize all that is desired and there is a combination of individual awareness and group awareness. Therefore, substantively to educate good citizens to ensure the realization of democratic societies in the global era, democratic education that is integrated through Citizenship Education is absolutely necessary with the aim of preparing citizens who are capable and act with democratic ethics.

\section{Role Of Citizenship Education As Ethical Democracy Education}

Nowadays, some people have the perception that democratic societies are defined as the same as free demonstration communities, which are essentially free to impose the will of their groups with the pressure of violence. The government also tends to be carried away by the thought that freedom is the root of democracy due to a fear of the international spotlight. As a consequence a democratic government must give full freedom to its citizens to express their opinions. Government policy to give freedom of opinion to groups in this society is actually an enemy of freedom under the guise of 
obedience to the constitution. True democracy requires good citizens, not only requires laws and regulations and institutions capable of upholding them, but also requires a democratic attitude. Therefore, substantially with long-term dimensions, to educate good citizens to ensure the realization of a democratic society, democratic education is absolutely necessary (Zamroni, 2003, pp. 15-17). Lickona (1991) adds that democracy is government by the people, so people are also responsible for shaping a life in the context of freedom for themselves (Lickona, n.d., p. 8). That means the community should have a virtuous attitude. In essence, in a democratic country that is responsible for democratic life is society itself in realizing a freedom, there needs to be ethical values that need to be upheld as a moral guide in carrying out democratic life itself.

Terminologically, citizenship education is an educational program that has the core of political democracy, expanded with other sources of knowledge, namely the positive influence of collaboration from school education, society, and parents. All of them are processed to train students to think critically, analytically, behave and act democratically based on Pancasila and the 1945 Constitution. Then the Directorate of General Education and European Culture (2005) through his book entitled "Citizenship Education at School in Europe" which is a collection of results a survey revealed that the idea of 'responsible citizenship' caused problems related to awareness and knowledge of rights and obligations. This is also closely related to citizenship values such as democracy and human rights, equality, participation, partnership, social cohesion, solidarity, tolerance for diversity and social justice. The concept of 'kewarganegaraan yang bertanggung jawab' (responsible citizenship) is now increasingly widespread, especially because a series of relevant recommendations and resolutions that promote the issue have been adopted by European Council member countries (Culture), 2005, p. 13). Citizenship education is expected to be able to form democratic citizens in the form of analytical and creative participation who have responsibility and uphold the values of citizenship to face the challenges of the 21st century. Globalization continues to grow in the 21 st century so that it affects every aspect of people's lives, including beliefs, norms, values, and behavior, as well as economics and trade (Banks, 2008: 132). Citizenship develops into global citizenship which can be understood as a multidimensional construction that depends on the interrelationships between the dimensions of social responsibility, global competence, and global citizen involvement (Morais and Ogden, 2011: 449). Cogan \& Derricot (1998) added that:

"education should and must develop pupils potential to the full and prepare them for the world in which they live. education for citizenship embraces both responsibilities and rights in the present and preparation for citizenship in adult life...schools must lay the foundations for positive, participative citizenship in two important ways: (1) by helping pupils to acquire and understand essential information and (2) by providing them with opportunities and incentives to participate in all aspects of school life". (Cogan \& Derricot, 1998, p. 26)

Based on Cogan \& Derricot's opinion, education must develop students' potential in full and prepare them to be able to live in the world where they live. Citizenship education includes responsibilities and rights in the present and prepares citizens in future lives. Schools must lay the foundation for citizenship and positive participation in two ways: (1) helping students to obtain and understand important 
information and (2) provide them with opportunities and incentive participation in all aspects of school life.

Citizenship education as an educational program is able to teach the core of political democracy, namely how democratic values are instilled through the learning process in order to form responsible students in the face of the global era. In the context of the reform process towards a new Indonesia with the conception of civil society as its ideal socio-cultural order, then paradigmatically citizenship education has three components or domains, namely (a) as a scientific study of civic science education; (b) as a curricular program for Citizenship Education; and (c) as a socio-cultural movement of citizenship, which coherently departs from essence and leads to the development of civic knowledge, civic virtues, and civic skills (Winataputra (2001-2006) as quoted (Winarno, 2014, p. 7,8). Morais and Ogden (2011) who find out about the dimensions of global citizenship can be developed in learning citizenship at school. There are three main dimensions which are often referred to in global citizenship, namely social responsibility, global competence (global competence), and involvement in global civic engagement (Mukhamad Murdiono, 2014:354). Whereas the most important thing is the context of global Citizenship Education developed in Indonesia referring to Pancasila as the Foundation of the State and the 1945 Constitution. The values of Pancasila (Godhead, Humanity, Unity, Population and Justice) can be used as transcendental (jangkar transendental) and foothold anchors for Indonesian citizens (Mukhamad Murdiono, 2014: 353).

Civic skills are the second essential component of Citizenship Education. Branson (1998) states "If citizens are to exercise their rights and discharge their responsibilities as members of self-governing communities, they not only need to acquire a body of knowledge such as that embodied in the five organizing questions just described; they also need to acquire relevant intellectual and participatory skills". It can be interpreted that if citizens practice their rights and fulfil their obligations as sovereign members of society, they not only need to master basic knowledge, but they need to have relevant intellectual and participatory skills (Winarno, 2014, p. 145).

As previously explained, moral is closely related to the doctrine of something good and bad that concerns human behavior and actions. In the context of ethics, everyone will have a feeling whether what is done is right or wrong, good or bad. This consideration is called the consideration of moral values. Consideration of moral values is an important aspect, especially in the formation of a good citizen as a goal of civic education (Sapriya, 2012, p. 29). Conceptions of morality need to be linked and integrated between moral thinking and moral actions and experiences in social life. Moral thinking can develop from the lowest level that is oriented towards obedience to authority for fear of physical punishment to a higher level, which is oriented towards fulfilling personal desires, loyalty to the group, carrying out tasks in the community in accordance with the rules and laws, to the highest supporting truth or essential values, especially regarding honesty, justice, respect for human rights, and social care. Moral actions that are in harmony with moral thinking are only possible through emotional and spiritual intelligence and habituation. Likewise, democratic actions will not color the life of a society, if the existing conditions do not encourage democratic and responsible action (Zuchdi, 2009, p. 7).

Based on this explanation, it can be concluded that the consideration of moral values include moral thinking and moral action is absolutely necessary in the life order of a democratic society now, given the freedom to interact and communicate (express 
opinions) as a manifestation of current political and government participation which is considered excessive, so that in the end it raises an ideal for the implementation of democracy "democracy not demo crazy". Referring to the reality of democracy in Indonesia, that democracy is subordinated to Citizenship Education with the aim of building students' awareness of their rights and obligations as citizens and being able to use them democratically and civilized in accordance with the concept of democracy.

\section{CONCLUSION}

The application of ideal democracy requires the existence of normative values and moral norms to regulate behavior in participating of democracy. In this case, Indonesia has ideal values and norms that govern all the behavior of its citizens, namely Pancasila, which in its principles contain the ideal of the state for the continuity of life in society, nation and state. The existence of Pancasila must be actualized and given new interpretations and adapted to national and global dynamics. True democracy requires good citizens. Therefore, democratic education that is integrated through Citizenship Education is absolutely necessary with the aim of preparing citizens who are able to act with democratic ethics. Citizenship education as an education program actually teaches the essence of political democracy, namely how the values of consultative democracy are instilled through the learning process to form responsible students in the face of the global era, because young citizens or the younger generation have an important role in international relations. The Context of Global Citizenship Education developed in Indonesia must refer to the values of Pancasila as the State Foundation and the 1945 Constitution (UUD 1945).

\section{REFERENCES}

Apiek Gandamana. 2017. Memaknai Demokrasi Pancasila. Jurnal Handayani PGSD FIP UNIMED, Vol. 7, No. 1.

Banks, J. A. 2008. Diversity Group Identity and Citizenship Education in A Global Age. in Educational Researcher 37 (3).

Bertens, K. (1993). Etika. Jakarta: Gramedia Pustaka Utama.

Cogan, J. J., \& Derricot, R. (1998). Citizenship for the 21st Century: An International Perspective on Education. London: Kogan Page.

Culture), E. C. (Directorate-G. for E. and. (2005). Citizenship Education at School in Europe (Survey). Belgium: Eurydice.

Farabi Fakih. 2015. Reading Ideology in Indonesia Today (review essay). Bidjdragen Tot De Taal-, Land-En Volkenkunde 171 (2015) 347. Downloaded from Brill.com 03/26/2019/ 05.13.30PM via free access

Hendro Muhaimin. 2013. Indonesia Now, Between Pancasila And Crisis Of Democracy In Indonesia. International Journal for Public Management and Politic Development, Vol. 1, No. 1.

Kaelan. (2013). Negara Kebangsaan Pancasila. Yogyakarta: Paradigma.

Kemahasiswaan, D. P. dan. (2016). Pendidikan Kewarganegaraan untuk Perguruan Tinggi. Jakarta: Kemenristek Dikti.

Lickona, T. (n.d.). Educating for Character: How Our Schools Can Teach Respect and Muhyar Fanani. 2017. The Impact Of The Declining In The Post-Indonesia Reformasi. Proceeding of Third International Conference on Social and Political Sciences (ICSPS 2017): Advences in Social Science, Education and Humanities Research 
(ASSEHR), Vol. 3, Atlantis Press.

Siswanto. 2017. Pancasila As Strategy To Prevent Proxy War. Jurnal Pertahanan, Vol. 3 , No. 2.

Sapriya. (2012). Pembelajaran Pendidikan Kewarganegaraan (PKn. Jakarta: Direktorat Jenderal Pendidikan Islam, Kemenag RI.

Udayana, U. (2013). Buku Ajar ( Bahan Ajar) Hak Menyatakan Pendapat Di Muka Umum.

Undang-Undang No. 09 Tahun 1998 tentang Kemerdekaan Menyampaikan Pendapat di Muka Umum.

Winarno. (2014). Pembelajaran Pendidikan Kewarganegaraan: Isi, Strategi, dan Penilaian. Jakarta: Bumi Aksara.

Winataputra, U. S., \& Budimansyah, D. (2012). Pendidikan Kewarganegaraan dalam Perspektif Internasional: Konteks, Teori, dan Profil Pembelajaran. Bandung: Widya Aksara Press.

Yudi Latif. 2012. Negara Paripurna: Historitas, Rasionalitas, dan Aktualisasi Pancasila. Jakarta: PT Gramedia Pustaka Utama.

Zamroni. (2003). Pendidikan untuk Demokrasi: Tantangan Menuju Civil Society. Yogyakarta: BIGRAF Publishing.

Zezen Zaenal Mutaqin. 2016. The Strong State And Pancasila: Reflecting Human Rights In The Indonesian Democracy. Journal Constitutional Review, Desember 2016, Vol. 2, Number 2.

Zuchdi, D. (2009). Humanisasi Pendidikan: Menemukan Kembali Pendidikan yang Manusiawi. Jakarta: Bumi Aksara. 